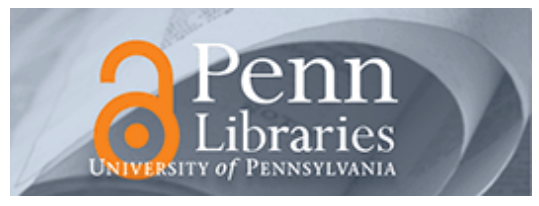

University of Pennsylvania ScholarlyCommons

$12-1-2007$

\title{
Biliteracy, Transnationalism, Multimodality, and Identity: Trajectories Across Time and Space
}

Nancy H. Hornberger

University of Pennsylvania, nancyh@gse.upenn.edu

Follow this and additional works at: https://repository.upenn.edu/gse_pubs

Part of the Education Commons

\section{Recommended Citation}

Hornberger, N. H. (2007). Biliteracy, Transnationalism, Multimodality, and Identity: Trajectories Across Time and Space. Linguistics and Education, 18 (3-4), 325-334. http://dx.doi.org/10.1016/ j.linged.2007.10.001

This paper is posted at ScholarlyCommons. https://repository.upenn.edu/gse_pubs/149

For more information, please contact repository@pobox.upenn.edu. 


\title{
Biliteracy, Transnationalism, Multimodality, and Identity: Trajectories Across Time and Space
}

\begin{abstract} multilingual youth and adults of diverse origins and communities from across the United States. These are multilingual lives and literacies located on the west coast, or in western mountain, southwest, and adult women refugees from Bosnia, Iran, and Sudan now residing in the intermountain west.

\section{Keywords}

biliteracy, transnationalism, multimodality, identity, immigration, language learning

Disciplines

Education
\end{abstract}

Herein, we are privileged to be given a close and detailed look at the lives and literacies of transnational midwest, or northeast U.S. There are New Yorkers of Dominican, Colombian, Bengali, and Chabad JewishAmerican heritage, Mexican immigrants from Guanajuato and Jalisco in lowa and California, respectively, 
Hornberger, N. (2007) Biliteracy, transnationalism, multimodality, and identity:

Trajectories across time and space. Linguistics and Education, 18(3-4), 325-334.

http://dx.doi.org/10.1016/j.linged.2007.10.001

\title{
Biliteracy, transnationalism, multimodality, and identity: Trajectories across time and space
}

\author{
Nancy H. Hornberger \\ September 2007
}

Appeared in special issue of Linguistics and Education on "Transnational Literacies: Immigration, Language Learning, and Identity,” edited by Doris S. Warriner (2007)

Herein, we are privileged to be given a close and detailed look at the lives and literacies of transnational multilingual youth and adults of diverse origins and communities from across the United States. These are multilingual lives and literacies located on the west coast, or in western mountain, southwest, midwest, or northeast U.S. There are New Yorkers of Dominican, Colombian, Bengali, and Chabad Jewish-American heritage, Mexican immigrants from Guanajuato and Jalisco in Iowa and California respectively, and adult women refugees from Bosnia, Iran, and Sudan now residing in the intermountain west.

The authors make clear that these cross-border movements of bodies, as of goods and information, are the direct result of globalization and specifically the internationalization of systems of production (Richardson-Bruna), processes which "tend to de-territorialize important economic, social and cultural practices from their traditional boundaries in nation-states" (McGinnis et al., citing Suarez-Orozco \& Qin-Hillard 2004: 14). The youth and adults we meet herein are transnational in that they have moved bodily across national borders while maintaining and cultivating practices tied -in varying degrees--to their home countries.

The accounts tell us, in-depth, about the multilingual and multimodal literacies and literacy practices these transmigrants bring with them and those they develop in their new contexts, and about the identities and social relations maintained and transformed through those literacy practices. The analyses show us how these local practices and identities are profoundly rooted in processes of globalization, and how they constantly shift and develop across time and space.

In reading and re-reading these essays, most of them the first time for the 2005 American Anthropological Association session at which they were presented, and all of them now for this special issue, several themes stand out for me in the cases presented: the image of transnational spaces, the emphasis on multimodal literacy practices, the demonstration of active construction and narration of self and identity through those practices, and the evidence of trajectories of literacy practices across time and space. Equally notable are the innovative, long-term, in-depth ethnographies the researchers have undertaken to plumb these themes. The following paragraphs comment on each theme in relation to the cases, followed by brief remarks on the ethnographic methods used. I conclude with reflections on the accounts in light of my own related ethnographic and theoretical work 
on the continua of biliteracy and the opening up of ideological and implementational spaces for multilingual language education policy and practice.

\section{Transnational spaces}

In every case, the lives of the individuals we are introduced to through these essays have been materially affected by global and transnational processes. In some cases, they are immigrants or refugees recently arrived to the U.S., while in others they are more settled first or second-generation immigrant or transnationally-affiliated individuals. Recent immigrants include María, a student at Luperón High School in New York City who arrived in 2004 at age 17 with her family from the Dominican Republic, one of the large and fast-growing Dominican immigrant population in the U.S.--and in particular New York City where they are the poorest of all ethnic and racial groups (Bartlett). Similarly, Gabriela, Rosa, and Aalia, newly arrived from Mexico in 2003 and in their first year as students at Captainville High in Iowa, are part of a large movement of Mexicans from Guanajuato to Iowa as a result of globalizing economic forces (Richardson-Bruna); and Alouette, Mary, Moría, Ayak, Alma, and Sheida, at Valley Instruction and Training Program in the Intermountain West, arrived in 2000 as adult refugees from war-torn areas of Africa, Europe, and the Middle East (Warriner). More settled immigrants include Carlota, Genobeba, and Maria, three young Latinas in the San Francisco Bay area whose families maintain ties with their home communities in Jalisco, Mexico (Sánchez); and the three transnational youth in suburban communities of New York, along a continuum from newly-arrived Julia from Colombia, to first-generation American-Bengali immigrant Subosh whose family maintains ties with the home community in India, and on to U.S. native-born Jewish-American Amanda who identifies with and is currently living in Israel (McGinnis et al.).

The cases show how, though these individuals move or have moved bodily across national borders, they maintain affinity ties and social networks in more than one country, in most cases their home and host countries. Transnationalism is differentiated from immigration, in that the latter involves a more permanent affiliation with the host country and separation from the home country while the former may imply no long-term intention to stay beyond what is economically necessary. Transnationalism thus lends itself to a dually-linked process of 'becoming other' to both home and host nationalcultural contexts (Richardson-Bruna, citing Trueba 2004).

Indeed, the accounts herein demonstrate how these youth and adults carve out and maintain transnational spaces - be they pedagogical spaces (Bartlett; Richardson-Bruna), social spaces (Sanchez), online spaces (McGinnis et al.), or employment spaces (Warriner); and document the ways in which they use, or seek to use, literacy practices within these spaces to position themselves as academically or socioeconomically successful. To be sure, some of the spaces are more social or geographic while others are instantiated primarily in the literacy practices themselves; yet in all cases the analyses here emphasize how these spaces afford opportunities for the construction and narration of self and identity through transnational literacies. 
Several of the papers also show or hint at how schools or adult education centers fall short on creating educational spaces that similarly enable or encourage the practice and development of transnational literacies. Warriner shows how structural constraints on Valley's adult ESL program — emanating from refugee policies and resulting in large class size, high turnover among students, great diversity of student backgrounds, varying literacy levels of students in any one class, and 2-6 month time limits on students' eligibility to enroll - combine to create a space dominated by "instant teaching" and a pervasive emphasis on standardized testing used to assess incoming students, measure their progress, and demonstrate their level of mastery to external agencies, funders, and employers. She argues for the need to "re-imagine the literacies of schooling" (citing Baynham 2004: 289), with instruction that would, for example, build on students' knowledge, engage their participation, and address the daily challenges they face outside class.

The other authors argue similarly. Educators need to consider the role transnationalism plays in the literacies and identities of students in their online literacy practices, for example, and look for ways to bridge their digital and academic worlds to provide "space for all youth to express and share their concerns and challenges related to local, national, and global issues and politics" (McGinnis et al.). Educators and educational researchers must look to the transnational social spaces students maintain in other countries, rather than define students only in light of the often stigmatized social spaces they inhabit in the U.S. (Sánchez). Educators and schools need to create local spaces - local school models-that take advantage of the linguistic, cultural, and social resources transnational students bring to their learning, as illustrated in the case of New York City's Luperón High School (Bartlett). All of these represent ways of opening up ideological and implementational spaces for transnational multilinguals' developing biliteracy and voice (cf. Hornberger 2002, 2006; Hornberger \& Johnson 2007).

\section{Multimodality and multilingualism}

We are told of numerous instances of multilingual language and literacy use: the high status given to Spanish at Luperón High (Bartlett); the three NYC suburban youths' online uses of Hebrew, Spanish, and different varieties of English on their blogs and personal webpages (McGinnis et al.); the juxtaposing of Spanish and English in tagging, branding, and shouting out literacy practices at Captainville High (Richardson-Bruna); and the privileging of Spanish in the bicultural-bilingual children's book written by the three Californian Latinas (Sánchez). All of these are instances of biliteracy, “ in which communication occurs in two (or more) languages in or around writing" (Hornberger 1990: 213).

In addition to highlighting and illustrating the multilingualism which is an integral part of these transnationals' biliterate repertoire, the accounts here also bring out the highly multimodal nature of their literacy practices. The literacy practices we encounter engage written and oral modes, as for example at Luperón High where Bartlett finds an emphasis on writing over oral language use which María is able to use to her advantage; but they also engage a range of other modes, especially those available through electronic media. McGinnis et al. define multimodality as the "integration of words with visual images, 
sound, streamed video, and/or paralinguistic symbols," all of which are illustrated in the cases presented here. The three NYC youths' blogs and personal webpages contain diary-like content, written in conversational register with a particular audience in mind, and including, in addition to the multilingualism mentioned above, images, streamed video, and music, as well as hybrid language- such as internet chat and slang, codeswitching, tone or voice expressed through choice of register or font and print size, and discourses of hip-hop, soccer, religion, feminism, and politics (McGinnis et al.)

The bicultural-bilingual children's book written and illustrated by the three young Californians is a multilingual/multimodal expression instantiating not only English, and Spanish as spoken by their family members and in their home communities in Jalisco, but also hand-drawn, culturally authentic illustrations (Sánchez). As for the newcomer Mexican students at Captainville High, Richardson-Bruna posits, along with others, that multimodal forms of meaning-making are premised on an understanding of literacy as the "ability to write oneself into an acquired fictional narrative," and she suggests that the whole body may be employed as semiotic resource, illustrating her point by description and analysis of informal literacy practices she has observed among the newcomer students: tagging via graffiti-like inscription of their own name, or that of their country or region of origin, in public spaces; branding by drawing attention to any kind of Mexican or Spanish-language reference on their clothes or accessories; and spontaneously shouting out their place of origin.

\section{Identity construction and narration of the self}

The youth and adults we meet in these accounts deploy their multilingual, multimodal (bi)literacy practices toward the construction and transformation of their transnational identities and social relations. Some transnational spaces are more favorable than others for enabling these processes, but while the authors recognize the multilevel constraints and challenges facing these individuals, their emphasis is on the transnationals' creative, agentive work in encountering and countering those obstacles.

In the alternative space designed and maintained by the staff of New York City's Luperón High, María is able to draw upon the resources provided by the school's local model of school success to position herself and be positioned over time as a "good" student; specifically, Bartlett demonstrates how María negotiates a good student identity by drawing on the high status of Spanish language and literacy at Luperón, the school's valuation of a particular school-based literacy that favors task-based literacy practices, the institutionally-supported opportunity narrative whereby effort and hard work are rewarded, and access to concerned administrators and caring teachers. While Bartlett takes note of the limited reach of the school's model of success given the low level literacy skills emphasized, she acknowledges the importance of María's success at positioning herself as a good student, rather than succumbing to the identity of "student with interrupted formal education (SIFE)" she was originally assigned.

"Online spaces afford youth a place to have a voice, to engage in important identity work, and to create texts around local, national and global issues that are important to them" (McGinnis et al.). One such space is Julia's MySpace personal website with its 
multilingual markers of her identities as 'Colombianita,' Latina, and bilingual as well as her engagement with the U.S. national political debate sparked by anti-immigrant legislation proposed in spring 2006. Subosh fills his MySpace site and xanga.com blog with multimodal expressions of his Indian heritage and pan-Asian but also specifically South-Asian affiliation, adopting African-American hip-hop discourse and the rap genre and explicitly questioning stereotyping and racism. Amanda's MySpace and Facebook sites and livejournal.com blog feature expressions and explorations of her multilayered identity as liberal feminist, orthodox Jewish-American, and Zionist with strong political and emotional ties to Israel, as well as her responses to local anti-Semitic acts and the global politics of the war between Israel and Lebanon. All three youths' online spaces amply demonstrate the ways in which they explore and negotiate complex multiple identities across race, ethnic, gender, socioeconomic, and nationalist lines, deploying their online literacy practices to claim membership in certain groups and position themselves as powerful in certain spaces (McGinnis et al.)

At Valley's ESL program, constraints of time and the continual influx of ever more students, coupled with the desire to maintain a uniform and fair process for all, inhibit any real consideration of more authentic means of assessment and pedagogy, leaving students instead with a pedagogy of literacy practices consisting mainly of reading, copying, responding to known-answer questions, filling in the blanks, and memorizing. As Warriner tellingly points out, these literacy practices are prioritized at the expense of other kinds of literacies, knowledges, and identities, most importantly the first-language literacies and multilingual competencies that crossed the border with the women refugees; while at the same time these practices are actually not preparing the women for the world beyond the classroom. The paradoxical lived experiences of Ayak and Alma epitomize the inadequacy of this pedagogical space for the refugees' construction of new identities in their new contexts: Ayak got herself a good job without completing the classes and taking the required tests, while Alma struggled to find work and advocate for herself even after taking all the classes and scoring well on the tests. Alma's exasperated "but I can't communication" captures the inadequacy well. Eventually she does, through her own perseverance, become the manager of a convenience store, but in both cases, the women seem to have negotiated successful new work identities for themselves in spite of, rather than because of, the Valley program.

Unfavorable pedagogical spaces and literacies are less explicitly detailed in the other essays, but nevertheless provide the backdrop for the alternative spaces, literacies, and narratives of self presented there. Bartlett and McGinnis et al. (just above) present alternatives to the institutionalized discourses that produce success or failure for transnational students in New York City schools; while Sánchez and Richardson-Bruna (just below) write against the backdrop of persistent gaps in socio-economic opportunity and well-being that accompany the identity of a U.S. Mexican student.

The collaborative book writing-and-illustrating project which the three young Latinas undertook with Sánchez created an out-of-school space in which all four of them could draw on transnational funds of knowledge and social relations in developing their retelling of the 'return to Mexico' narrative, a recurring narrative in the lives of 
transnational Mexican families wherein the family returns yearly to Mexico to celebrate, in their natal community, a baptism, wedding, or other significant family event. Children raised in transnationalized households experience "certain flows of people, money, labor, goods, information, advice, stories, languages, care, and love ... in either direction" (Sánchez), and it is in this context that the three young women develop their narrative about the twins Xiri and Pepito who travel to Mexico during their winter break with their parents and older sister, Chayo, to celebrate Chayo's quinceañera (the young girl's fifteenth birthday, traditionally celebrated as a life-marker event in Mexico). In their retelling, "the young women author themselves .. and construct a meta-narrative of their heretofore 'unofficial' (Dyson 1994) transnational lives" (Sánchez), thereby producing a counterstory to the deficit portrayals of Mexican immigrant families pervasive in popular media discourse.

If transnational identity is quintessentially about becoming 'other' with respect to both the home and host cultures (Trueba 2004:88), newcomer Mexican students' informal literacy practices of tagging, branding, and shouting out at Captainville High can be understood as "literacies of display" (Hamilton 2000: 20) of those transnational identities. All of these practices take elements of the immediate U.S. context and, onto those, inscribe youth's membership in the imagined transnational community of Mexicans living outside of Mexico (Trend, 1994). This repositioning marks these youth against the norm of "American," but also positions them as "other" to their context of origin in Mexico (Richardson-Bruna).

Tagging, branding, and shouting out practices thus function as affinity group Discourses (Gee 2000:99) through which minority youth create "safe houses" within a dominant institution (Canagarajah 1999:121). Indeed, students invariably told Richardson-Bruna that their goal in the tagging, branding, and shouting out practices was to honor their homeland (honrar a la patria), signalling the impulse to celebrate their close ties to Mexico. Richardson-Bruna asks whether these informal literacy practices can then travel into the more formal classroom context, and finds that they do.

\section{Trajectories across time and space}

Richardson-Bruna's "traveling tags" epitomize a striking contribution of all the essays, which is that they not only provide in-depth portraits of transnational identities and multimodal literacy practices, but also trace their trajectories across time and space. Whether mapping from outside to inside the classroom, across classrooms, across virtual online spaces, from California to Mexico and back, or local to global relations and processes, and whether across one-two-or-multiple years, the authors trace how individuals' transnational identities and practices develop, shift, transform and are transformed as they move across space and time. Significantly, they consider the implications this has for educational policy and practice.

Richardson-Bruna takes the informal literacy practices she observed at Captainville High to be instances of transcultural repositioning (Guerra 2004) wherein the newcomer Mexican students move back and forth between and among different languages, social classes, and artistic forms corresponding to their two national contexts - a "fluent movement between cultural frames essential to their student identity." After identifying 
tagging, branding, and shouting out practices in year two of her research, she returns to the videotaped lessons of year one to discover whether these practices are also present in the formal classroom setting. She finds - and analyzes in detail -- an instance of three newcomer girls, Gabriela, Aalia, and Rosa, the 'tagging trio,' severally tagging the whiteboard on the final day of a week-long pig dissection activity in their English Learner (EL) Science class.

Her analysis of the taggings and of the classroom context in which they occurred shows that these informal literacy practices, transported into the classroom, function not as oppositional behavior as might first appear, but rather as literacies of assistance, or requests by transnational youth for help in "developing cultural fluency between their transnational identity and the classroom context." The tagging trio had not had the kinds of classroom-sanctioned opportunities to engage with the teacher that other students in the class did, but rather were positioned through their interactions with the teacher as variously noncompliant, incompetent, or ineffectually deferential. Yet, their otherwise on-task behavior and completion of the activity do not suggest resistance or defiance, but rather an eagerness to participate and be recognized. The taggings are, Richardson-Bruna suggests, instructionally significant signposts, for teachers to notice.

Sánchez similarly emphasizes the importance of cultural fluency, or cultural flexibility as she terms it, in the lives of transnational youth - in this case, the three young Latinas as they move back and forth between their worlds, whether in their transnationalized homes and communities in California or in their return trips to Mexico. Cultural flexibility entails authentic experience in different cultural worlds and it is this cultural authenticity that the young women bring to their book-making project. Sánchez analyzes their culturally authentic rendering of transnational U.S.-Mexican families in terms of three language and literacy practices the young authors transport from the transnational social spaces they inhabit into their retelling of the narrative: co-constructed story-telling, privileging of Spanish, and use of pictorial artifacts. The juxtaposition of the photograph of Genobeba's grandmother's kitchen in Mexico and the pictorial representation of a rural Mexican kitchen in the book vividly exemplifies how these practices move and are transformed, across space and time.

The book-writing project traces another trajectory of shifting literacy practices and identities as well, namely that of the young women's own reading and writing practices and their identities as authors: whereas in year one of Sánchez' study, the three showed no interest in engaging in schooled literacy practices in their weekly meetings with her, by year three, after spending the intervening year making return trips to Mexico together, they initiated the book-writing project and became heavily immersed in reading and writing activities, emerging as successful authors of a published and well-received book. Sánchez is quite clear that schools could do a better job of fostering the kinds of bilingual language and literacy development and critical literacy practices that led to these young women's production of their charming and effective countertext to the prevalent image of the Mexican immigrant/border-crosser as criminal. 
One school that is explicitly designed to provide a more favorable educational space for newcomer immigrant youth and in particular Dominican youth, is Gregorio Luperón High School in New York City, founded in the 1990s by a group of Dominican activists. In this space, where staff and students share ethnolinguistic backgrounds and the immigrant opportunity narrative of schooling prevails, and where bilingual literacies are fostered and encouraged, Bartlett is able to trace María's trajectory from SIFE to good student across a two-year period, in which María's determined perseverance at her school tasks, despite her difficulties with English and her significant family responsibilities at home, earn her the respect and support of teachers and administrators at the school. Over the course of this time, María succeeds in moving up through a series of levels of English language classrooms and repositioning herself as a good student by, for example, assiduously completing her work even without fully understanding it, drawing on the school's biliteracy practices which enable her to use Spanish for many of her oral and written assignments, associating with high-achieving students, and spurning teachers who do not have a high opinion of her abilities while aggressively seeking teachers whom she feels she can learn from. The tracing of this student's biliteracy trajectory suggests perhaps above all, in Bartlett's words, "the importance, for bilingual immigrant youth, of a local, school-based model of success that values students' first languages as a resource."

The trajectories that McGinnis et al. and Warriner trace in their accounts are more virtual or displaced than the physically present classroom, school, and community spaces and the documented multi-year timespans described above, but they are no less real and significant for the shifting and developing literacies and identities of the individuals involved. McGinnis et al. suggest that educators have much to learn about the multifaceted lives and identities of youth as they move across codes and modes on their digital blog and website spaces, redesigning and refining them over time. Their online texts and spaces shape and are shaped by new meanings and subjectivities; and are therefore profoundly transformative practices for the youth (McGinnis et al., citing Kress 2003).

Warriner's account, located in the Valley program and the narratives of six women refugees enrolled there, elicits narrative traces of trajectories back through time and space to the women's home countries, and forward to their progress through the ESL program and into employment. She argues that the literacy practices and identities fostered at Valley, shaped as they are by global and local economic forces, equip learners only for low-wage, low prestige, and insecure jobs, thereby solidifying and perpetuating race, language, and class distinctions, and contributing to the continued marginalization of these refugee women and other transnational refugees. The trajectories of the women instantiate the ways that local practices are not only influenced by global events and processes, but actually serve the functions of globalization; in this way, Warriner demonstrates how the trajectories of individuals' literacy practices and transnational identities are caught up in processes that are simultaneously global, local, transnational, and individual. 


\section{Ethnographic explorations}

It is no accident that the in-depth ethnographic methods the researchers chose yield the richly-detailed and multilayered accounts we find here. The textured insights as to transnational spaces, multimodal literacies, identity construction, and time-space trajectories are plumbed by ethnographies which are correspondingly multi-sited, multimethod, participatory, and long-term.

All the cases and analyses reported are the result of larger ethnographic studies of up to four years, in which the researchers have taken multiple and often highly participatory roles over time as researchers, teachers, and teacher-researchers, in many cases involving study participants also as co-researchers. Bartlett's collaborative research team includes colleagues and graduate students at Teachers College. McGinnis' co-researchers and coauthors Goodstein-Stolzenberg and Costa Saliani are also the high school teachers of the students whose literacy practices they study. Richardson-Bruna's role shifted in the second year of her project from researcher to teacher-researcher co-teaching in the classrooms she studies. Sánchez documents and interprets the literacy practices of the three young Latinas who are also her co-researchers, co-presenters, and co-authors. Warriner takes on a focused researcher role after first having worked as teacher and orientation coordinator at the adult ESL center whose literacy practices she studies.

The ethnographers adopt innovative multi-sited and multimethod approaches, in keeping with the questions they investigate. Multi-sitedness in these cases extends from multiple classrooms in one school or adult education center (Bartlett and Warriner) to multiple schools (McGinnis et al., Richardson-Bruna, Sánchez) to transnational homes and communities in the U.S. and Mexico (Sánchez and Richardson-Bruna). All of the ethnographers employ the tried-and-true trio of ethnographic data collection via participant-observation, interview, and document review, but there is also a noticeable multimodality across all of these, mostly enabled by the boom in electronic and digital technologies: participant-observation accompanied by extensive use of photography and audio and video recording; a range of recorded interview approaches, both individual and group, in-depth and focal; and review of a wide array of documents and texts, many of them produced, displayed or archived online.

Also notable and noticeable in these ethnographic studies is the stunning array of theoretical frames and conceptual tools the researchers avail themselves of in framing and analyzing their ethnographic data. Figured worlds and cultural artifacts (Holland et al. 1998), circulating models and multiple timescales (Wortham 2006), and the social production of school success and failure (McDermott \& Varenne 1995) are among Bartlett's key conceptual tools. McGinnis et al. draw on notions of multimodal design (New London Group 2000, Kress 2003), situated literacy practices (New Literacy Studies, Barton 1994, Gee 1990, Street 1993) and multiple social identities (Hall 1997). Interactional ethnography (Castanheira et al. 2001, Bloome et al. 2005), literacies of display (Hamilton 2000), hybrid discourses (Kamberelis 2001), discourse communities (Swales 1990), transcultural repositioning (Guerra 2004), and resisting resistance (Brown 1996) make up part of Richardson-Bruna's repertoire. Funds of knowledge (González, Moll, \& Amanti 2005), cultural authenticity (Fox \& Short 2003) and narrative as an 
iterative form (Hymes 1996) inform Sánchez' analysis. Warriner grounds her argument in concepts such as literacy as a situated social activity and process (Street 1984, Collins $\&$ Blot 2003), authenticity and gate-keeping functions of testing (Leung \& Lewkowicz 2006), the cultural politics of ESL (Pennycook 1994, 2000), and the material consequences of literacy (Luke 2004). All draw on fine-tuned and close analysis of the particular, informed by broader sociotheoretical frameworks. Their conceptual tools, and the social theoretical models underlying them, contribute to the rich and revealing interpretations these authors are able to provide.

\section{Continua of biliteracy}

As one who has become accustomed over the last twenty years or so to analyzing instances of biliteracy using the continua of biliteracy (Hornberger 1989, 2003), I am inevitably drawn to do so here - and these instances fit remarkably well. Transnational spaces are after all contexts of biliteracy, multimodal communicative practices are biliterate media, identities constructed and negotiated through transnational literacy practices are expressions of biliterate content, and trajectories across time and space are pathways of biliterate development. The biliterate instances depicted here - the Guanajuato students' traveling tags, the Jalisco Latinas' retelling of the return-to-Mexico narrative in their book-making project, the NYC youths' multimodal blogs and webspaces, María's academic success within Luperón High School's alternative local model of success, and the refugee women's negotiation of their individual pathways from ESL classes to employment - provide richly complex accounts of the contexts, content, and media through which multilinguals creatively develop biliteracy and voice.

The analyses here, and the instances they depict, broaden and deepen the continua of biliteracy in ways that could not have been foreseen twenty years ago - neither in the real world nor in the research world. I am struck simultaneously by how different and how much the same our world--and our ways of describing our world--are today, as compared to a quarter century ago when I started to research these issues. Transnational communities, multimodality, and global flows were much less visible then, and the conceptual tools with which to study them much less developed, and yet the underlying realities of complexly multilingual contexts, richly diverse repertoires of communicative media, socially constructed meanings in textual content, and multiple potential trajectories of multilingual language and literacy development remain as enduringly and endearingly human now as then. Equally, or more so, these multilingual learners deserve our continual reimagining and opening up of educational spaces that foster their ongoing development and creative transformation of their transnational -and biliterate-lives and literacies.

\section{References}

Barton, D. (1994). Literacy: An introduction to the ecology of written language. Oxford, UK: Blackwell.

Baynham, M. (2004). Ethnographies of literacy: An introduction. Language and 
Education, 18(4): 285-290.

Bloome, D., Carter, S.P., Christian, B.M., Otto, S. \& Shuart-Faris, N. (2005). Discourse analysis and the study of classroom language and literacy events: A microethnographic perspective. Mahwah, NJ: Lawrence Erlbaum.

Brown, M.F. (1996). On resisting resistance. American Anthropologist, 98, 4, pp. 729749.

Canagarajah, A.S. (1999). Resisting linguistic imperialism in English teaching. Oxford: Oxford University Press.

Castanheira, M.L., Crawford, T., Dixon, C.N., \& Green, J.L. (2001). Interactional ethnography: An approach to studying the social construction of literate practices. Linguistics and education 11,4, 353-400.

Collins, James and Richard K. Blot (2003). Literacy and Literacies: Texts, power \& identity. New York: Cambridge University Press.

Dyson, A. H. (1994). “I'm gonna express myself”: The politics of story in children's worlds. In A. H. Dyson \& C. Genishi (Eds.), The need for story: Cultural diversity in classroom and community (pp. 155-171). Urbana, IL: National Council of Teachers of English.

Fox, D.L. \& Short, K.G. (2003). Stories matter: The complexity of cultural authenticity in children's literature. Urbana, IL: NCTE.

Gee, J. (1990) Social Linguistics and Literacies: Ideology in Discourses. London: Falmer Press.

Gee, J.P. (2000-1). Identity as an analytic lens for research in education. Review of Research in Education (pp. 99-125). Washington, DC: American Educational Research Association.

González, N., Moll, L. C., \& Amanti, C. (Eds.) (2005). Funds of knowledge: Theorizing practice in households, communities, and classrooms. Mahwah, NJ: Erlbaum Associates.

Guerra, J.C. (2004). Emerging representations, situated literacies, and the practice of transcultural repositioning. In M.H. Kells, V. Balester, \& V. Villanueva (Eds.) (pp. 7-23), Latino/a discourses: On language, identity, and literacy in education. Portsmouth, NH: Heinemann.

Hall, S. (1997). Old and new identities, old and new ethnicities. In A. King (Ed.), Culture, globalization and the world system: Contemporary conditions for the representation of identity (pp. 41-69). Minneapolis: University of Minnesota Press.

Hamilton, M. (2000). Expanding the new literacy studies: Using photographs to explore literacy as social practice. In D. Barton, M. Hamilton, \& R. Ivanic (pp. 16-34), Situated literacies: Reading and writing in context. London and New York: Routledge.

Holland, D., Lachicotte, W., Skinner, D., and Cain, C. (1998). Identity and Agency in Cultural Worlds. Cambridge: Harvard University Press.

Hornberger, N. H. (1989). Continua of biliteracy. Review of Educational Research, 59(3), 271-296.

Hornberger, N. H. (1990). Creating successful learning contexts for bilingual literacy. Teachers College Record, 92(2), 212-229.

Hornberger, N. H. (2002). Multilingual language policies and the continua of biliteracy: 
An ecological approach. Language Policy, 1(1), 27-51.

Hornberger, N. H. (Ed.). (2003). Continua of biliteracy: An ecological framework for educational policy, research and practice in multilingual settings. Clevedon, UK: Multilingual Matters.

Hornberger, N. H. (2006). Voice and biliteracy in indigenous language revitalization: Contentious educational practices in Quechua, Guarani, and Maori contexts. Journal of Language, Identity, and Education, 5(4), 277-292.

Hornberger, N. H., \& Johnson, D. C. (2007). Slicing the onion ethnographically: Layers and spaces in multilingual language education policy and practice. TESOL Quarterly, 41(3).

Hymes, D. (Ed.). (1996). Ethnography, linguistics, narrative inequality: Towards an understanding of voice. London: Routledge.

Kamberelis, G. (2001). Producing heteroglossic classroom (micro)cultures through hybrid discourse practice. Linguistics and Education 12, 1, 85-125.

Kress, G. (2003). Literacy in the new media age. London: Routledge.

Leung, C. \& Lewkowicz, J. (2006). 'Expanding horizons and unresolved conundrums: language testing and assessment'. TESOL Quarterly 40,1: 211-34.

Luke, A. (2004). On the material consequences of literacy. Language and Education, 18(4): 331-335.

McDermott, R. and Varenne, H. (1995) Culture as Disability. Anthropology and Education Quarterly 26, 323-348.

New London Group (2000) A pedagogy of multiliteracies: Designing social futures. In B. Cope \& M. M. Kalantzis (Eds.)., Multiliteracies: Literacy learning and design of social futures, (pp. 9-37) London: Routledge.

Pennycook, A. (1994). The cultural politics of English as an international language. New York: Longman.

Pennycook, A. (2000). The social politics and the cultural politics of language classrooms. In J. K. Hall and W. G. Eggington (eds.), The Sociopolitics of English Language Teaching. Buffalo, NY: Multilingual Matters (pp. 89-103). Buffalo: Multilingual Matters, Ltd.

Street, B. (1984). Literacy in theory and practice. New York: Cambridge University Press.

Street, B. V. (Ed.). (1993). Cross-cultural approaches to literacy. Cambridge: Cambridge University Press.

Suárez-Orozco, M. \& Qin-Hillard, D. (2004). Globalization. In M. Suárez-Orozco \& D. Qin-Hillard (eds.), Globalization, culture and education in the new millennium (pp. 1-37). Berkeley: University of California Press.

Swales, J. (1990). Genre analysis: English in academic and research settings. Cambridge: Cambridge University Press.

Trend, D. (1994). Nationalities, pedagogies, and the media. In H.A. Giroux \& P. McLaren (Eds.) (pp. 225-241). Between borders: Pedagogy and the politics of cultural studies. New York: Routledge,.

Trueba, E.T. (2004). The new Americans: Immigrants and transnationals at work. New York: Rowman \& Littlefield.

Wortham, S. (2006). Learning identity: The joint emergence of social identification and academic learning. New York: Cambridge University Press. 